\title{
Redefining Working Conditions in Europe
}

\author{
Patricia Vendramin and Agnès Parent-Thirion
}

\begin{abstract}
By the standards of the International Labour Organization (ILO), working conditions in Europe are relatively enviable. This chapter, however, highlights a number of trends that are both counterproductive for companies and harmful for employees and the community. Over the past twenty years, the conditions and forms of work organisation have been changing in ways that no longer meet the evolution of the working population. In particular, they no longer match the high and 'expressive' expectations of ever more qualified employees, the increasing number of women in the labour market, changing lifestyles and an ageing workforce. During this time, the notion of 'quality of work' has sometimes been high on the political agenda. It is now being taken into consideration at the European level thanks to the new European Pillar of Social Rights and the concept of sustainable work. This chapter explores academic and political discourses on the quality of work and provides a review of working conditions in Europe and current challenges in this area. It is based on successive waves of the European Working Conditions Survey (EWCS) conducted by the European Foundation for the Improvement of Living and Working Conditions (Eurofound). In conclusion, we ask whether the notion of sustainable work can be incorporated into the ILO's forwardlooking approach and become a decisive factor in the future of the world of work.
\end{abstract}

\section{Introduction}

By the standards of the International Labour Organization (ILO), working conditions in Europe are far from problematic. Admittedly, seen from a long historical perspective, they have steadily improved and are even extremely enviable in comparison with those prevailing in other regions of the world. Nevertheless, the record of the world of work in Europe is far from unblemished and active players in that world, whether associated with the state or not, need to be attentive to the trends of the past twenty years. Working conditions seem to be evolving in a way that seems to fly in the face of workers' expectations: job insecurity has increased, loss of meaning and lack of recognition prevail in many professional environments, and psychosocial and musculoskeletal

(C) PATRICIA VENDRAMIN AND AGNÈS PARENT-THIRION, 2019 | DOI:10.1163/9789004399013_014

This is an open access chapter distributed under the terms of the prevailing CC-BY-NC license at the time of publication. 
problems have become alarmingly widespread. These developments are not favourable to workers or to companies, which are now obliged to struggle with absenteeism, the lack of commitment of their employees, and difficulties in retaining staff. Virtuous practices cannot be prescribed by law. They are driven by environments conducive to their development. At the societal level, working conditions must also remain compatible with the ageing of the working population and the lengthening of careers. In addition, the transformation of lifestyles and the full participation of women in the labour market require a new balance. To reflect current working conditions in Europe, this chapter traces the fluctuations of the political commitment to the quality of work, analyses a series of indicators representative of the state and evolution of these conditions and, by way of conclusion, raises a number of contemporary issues in this area at the level of Europe and the ILO.

For twenty years, questions and debates about working conditions in Europe have successively focused on three concepts: quality of work, flexicurity and sustainable work. As a major focus of the European Union's (EU's) economic and development policy between 2000 and 2010, the Lisbon Strategy set itself the goal of creating 'more and better jobs'. But following the failure of its implementation, and the global financial crisis of 2008 , another approach to work emerged: flexicurity. Recently, the notion of sustainable work seems to have prevailed. It offers a more convincing response to an ageing population, to the desire to increase the proportion of older workers in the labour force, and also to the marked increase in musculoskeletal and psychosocial problems among workers of all ages.

\subsection{Interest in the Quality of Work is Gradually Overshadowed by Flexicurity}

Since the 1980s, the world of work has undergone profound changes. New forms of work organisation (NFWO) have gradually been put in place and have considerably modified both the way of working and the criteria for defining the quality of work. The industrial model, the Fordist company, and bureaucratic red tape have given way to new modes of organisation seen as better adapted to the challenges of an ever evolving globalised economy. These NFWO are based on flexibility, networks, technologies, just-in-time flows, customer strategy, quality, diversification and customisation.

In tandem with this, the profile of the workforce has changed: women are increasingly present in the labour market and the average level of workers' 
qualifications has increased. Workers are now seeking to make sense of their professional activity; they need recognition and they aspire to personal growth and development. So-called 'expressive' expectations of work have gradually assumed considerable importance (Méda and Vendramin, 2016). But NFWO have provided only very partial answers and, as a result, generated new fractures in the world of work, most often related to job status and opportunities for self-fulfilment.

These changes have occurred in a context in which the economic position of certain social groups-including the young and the least qualified-has become chronically insecure. Their increasingly evident malaise is indicative both of their dissatisfaction and of some of the dysfunctions that prevail in organisations. When work no longer guarantees long-term economic security and leads to dissatisfaction, thus undermining the physical and mental health of workers-musculoskeletal and psychosocial disorders have become more widespread over this period - its 'quality' inevitably becomes a political issue. But this concept of quality of work is complex and reflects a specific way of considering reality and the compromise that binds all those involved together.

Since the beginning of the new millennium, many researchers have tried to define and measure the quality of work. They have proposed many indices and definitions that inevitably highlight the multidimensional nature of the notion of quality of work and employment. Eurofound (2002 and 2012), for example, suggested a model with four dimensions: wages, the quality of the working contract, working time, and the intrinsic quality of the work (skills development, physical environment, social environment, work intensity). For their part, Francis Green (2006), Andrew Brown et al. (2007) and Francis Green and Tarek Mostafa (2012) have highlighted the content of work, working conditions and conditions of employment (including wages). The Laeken indicators, introduced by the European Union in 2001, are based on a set of ten dimensions that cover the labour market, working conditions and social policies (Davoine et al., 2008). The concept of 'decent work' - developed by the ILO-focuses more on labour law, social protection and social justice, all themes consistent with the global reach of the ILO's work (Ghai, 2003). Many other studies have proposed definitions and indices relating to the quality of work, including Rafael Muñoz de Bustillo et al. (2009), Holman and McClelland (2011), and the European Trade Union Institute (Leschke and Watt, 2008) and its Job Quality Index (JQI). This academic effervescence has highlighted the multidimensional nature of the concept, but also the fact that it lies at the crossroads of research, public policies and ethics. Quality of work remains difficult to define because the different social players do not agree on any of its many components, and this definition involves a certain conception of work. 
Thus, the fact that European politicians have chosen to favour the concept of job quality rather than that of decent work is not just a question of semantics. Prieto and Serrano Pascual (2014) saw this decision as a way of depoliticising the social question. Naming a social fact contributes to producing it as a political phenomenon. Therefore, treating work from the point of view of dignity or decency rather than of quality reflects, in the view of these authors, a shift from the notion of justice to that of efficiency. The political issues associated with this shift in perspective are important. The concept of decent work is based on a vision of social justice and involves a certain moral judgement. Born of the desire for social reformism that prevailed at the end of the nineteenth century - at the time of the invention of the welfare state and in the wake of the workers' movements - the idea of decent work comes with a normative ambition: to develop the social rights of work and workers. In contrast, the fuzzy, relative, and multidimensional concept of job quality is closely related to its economic effects on productivity and profitability. In the European strategy, improving the quantity and quality of jobs is the element needed to connect a competitive economy with greater social cohesion. The 'quality' promoted and recommended refers, in essence, to the application of good practices. For Prieto and Serrano Pascual, the notion of job qualityunlike that of decent work - tends to dissociate the issue of 'good work' from the social question and to favour a 'logic of recommendations of good practice' rather than the demanding of certain rights. The European Commission, in the authors' view, has tried to replace 'decent work' with job quality; 'decent work' is more expensive to set up and much less compatible with its economic policy and its ideological frame of reference.

In the first decade of the new millennium, the theme of job quality spread beyond academia to become a matter of international economic policy, notably through the ILO's 'decent work' agenda and the Lisbon Strategy of the EU. Between the end of the 1990s and 2003, the EU implemented a seemingly ambitious employment policy and social agenda through various directives and the European Employment Strategy (EES). In 2001, job quality became a goal of the EES in its own right. But the political initiatives for the quality of work and employment came up against the principles laid down by the Organisation for Economic and Co-operation and Development (OECD) and subsequently by the European Commission, with the aim of placing competition at the heart of the European project. After the mid-term review of the Lisbon Strategy carried out in 2004 by Wim Kok, former Prime Minister of the Netherlands, the notion of flexicurity finally overshadowed the notion of quality of work.

In 2007, the European Commission published a communication entitled 'Towards common principles of flexicurity: More and better jobs through 
flexibility and security' (European Commission, 2007). It defined flexicurity as 'an integrated strategy to enhance, at the same time, flexibility and security in the labour market' (European Commission, 2007, 10). The concept was appealing (Barbier, 2007; Serrano Pascual, 2008) because it allowed for the reconciliation of opposites and could become an objective for all member states, regardless of the specificities and traditions of each one (the idea was that each country could follow its own 'flexicurity course' adapted to the particularities of its labour market). However, flexicurity has essentially remained a political slogan that has resulted in more flexibility but little security (Bevort et al., 2006; Serrano Pascual, 2012). After 2008, the EU, faced with economic recession, abandoned its social objectives, including the quality of work.

With its 'Europe 2020' strategy (a growth strategy for Europe in the 2010s), the Commission focused on poverty at the expense of job quality, at the risk of allowing the latter to be drowned out by the issue of impoverished workers (Bothfeld and Leschke, 2012) and thus reducing employment to its instrumental dimension of ensuring livelihood and security of existence. The growing inequalities in Europe relegated the concern for job quality to the background. In a Europe deprived of a social project, the Commission has recently decided to implement an ambitious project for a European Pillar of Social Rights aimed at ensuring the proper functioning of labour markets and social protection systems. The future will tell whether putting working conditions back at the top of European priorities will actually improve the lot of workers.

\subsection{A New Perspective: So-called Sustainable Work}

In a context of demographic ageing, longer working lives, and the development of contemporary work-related ills, including musculoskeletal and psychosocial disorders, a new approach to working conditions has gradually moved out of the scientific field and into the the political realm: long-term or sustainable work. This concept, which seemingly replaces that of quality of work, originated in the notion of sustainable development, defined in the Brundtland Report as follows: it is development that 'meets the needs of the present without compromising the ability of future generations to meet their own needs' $(S, 1987,39$, para. 49). This approach has been applied to the way companies operate, and in particular to the nature of work.

The concept of sustainable work was born within the Swedish research programme SALTSA, ${ }^{1}$ more specifically in the framework of the international research project 'From intensive to sustainable work systems' coordinated, from

1 The SAltsa programme is a joint undertaking by the Swedish confederation of employees (LO, SACO and TCO) and Sweden's National Institute for Working Life (now closed), 
1996 to 2007, by the National Institute for Working Life (NIWL) in collaboration with labour organisations. The first studies produced by the researchers involved - who came from thirteen countries and eight scientific disciplines (including management sciences, ergonomics, sociology, software design, psychology and educational sciences) - were synthesised in a reference work entitled 'Creating Sustainable Work Systems' (Docherty et al., 2002). In this document, the notion of a sustainable work system refers to a system that can 'maintain and reproduce the given human and social resources or even extend them' (Docherty et al., 2002, 101), a definition consistent with a logic similar to that of the Brundtland Report.

Thus, unlike the so-called intensive work system, the sustainable work system must be able to regenerate and develop the human and social resources that it mobilises. When that reference work was being written, the intensive system seemed inadequate, since the organisation of work and the way in which the companies associated with it operated were putting increasing pressure on an ageing workforce. The field of reflection and action on sustainable work arose from these contradictory pressures.

The concept of a sustainable work system was originally sociotechnical in nature (Barisi, 2011). It was part of a vision that from the outset posited human activities as a place where human, social and environmental factors could overlap and the technical and ecological resources of the system be integrated into questions of well-being at work and of human resources (physical, cognitive, emotional and social). Subsequently, ergonomists and sociologistsamong others - took it up and reformulated it from the problem of ageing at work (Gollac et al., 2008), a process in the course of which it lost its sociotechnical component. Moving into the scientific field, the concept of a sustainable work system gave birth to a reflection on the notion of sustainable work, which resulted in a refocusing on the quality of work, in all its dimensions, and a strengthening of the notion of individuals' trajectories. The approach to sustainable work therefore involves taking into account the effects of working conditions - cumulative over time - and their relationship with private life in the long term. It combines the analysis of work and the focus on individuals as a whole, with all their characteristics, their trajectories and the constraints that weigh on them. In particular, this approach guided the creation of the Eurofound Work Programme 2013-16 as well as the 2016-17 campaign of the European Agency for Safety and Health at Work (EU-OSHA) entitled 'Healthy Workplaces for All Ages'.

a government agency for the conduct of research, development and educational work on work-life issues. 
The proponents of this new perspective still faced two conceptual challenges: agreeing on a definition of the quality of work and integrating the dynamic dimension of individuals' trajectories. These issues are both conceptual and strategic. The definition of the quality of work is being discussed in different scientific disciplines and in debates between public decision makers. And while the need to take into account the dynamic dimension of individual trajectories seems to be unanimously recognised, the operationalisation of this perspective is a complex scientific challenge and its implementation will require new approaches. The fraught national debates on arduous work accounts $^{2}$ reflect the difficulties in realising this perspective.

The authors of a report entitled 'Sustainable work and the ageing workforce' (Vendramin et al., 2012) include in their analysis framework a set of variables aimed at a better understanding of the sustainability of work. To the traditional parameters defining the quality of work (Eurofound, 2002), they add health variables and more subjective components connected with the relation to work. Their analytical framework, shown in Figure 13.1 in the form of a daisyshaped graph, includes five axes:
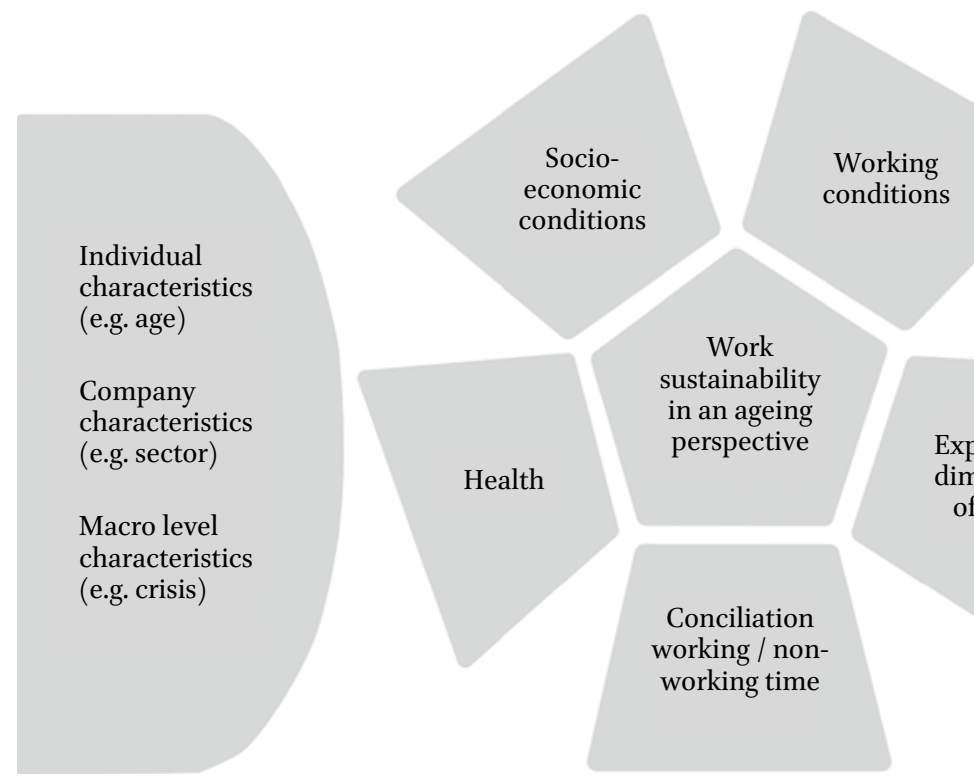

FIGURE 13.1 Work Sustainability from the Perspective of Ageing SOURCE: VENDRAMIN ET AL. (2012).

2 For further information on arduous work accounts see the website https://www.eurofound .europa.eu/publications/article/2017/france-occupational-personal-accounts-take-effect (accessed on 31 July 2018). 
- socio-economic security: job status and job security;

- working conditions: changes in work, exposure to risks, non-standard working time, flexibility, work pace and emotional pressure;

- health: physical health, psychological health and indicators of perceived health;

- the expressive dimension of work: autonomy, work content, job satisfaction, recognition, skills development and the social environment;

- the balance between working/non-working time: the balance between work and non-work commitments and arrangements relating to working time arrangements.

The following section provides an analysis of working conditions in Europe and their evolution along these five axes.

\section{The Evolution of Working Conditions: A Halftone Portrait}

The five-year Eurofound survey on working conditions is a valuable source of information on the evolution of working conditions in Europe, thanks to the richness of its questionnaire, the extent of its geographical coverage and the longevity of the arrangements that have underpinned it (since 1991). This section, structured along the five axes of sustainable work, includes some of its key indicators relating to the state of working conditions in Europe and their evolution over 25 years. It reports the data for the $28 \mathrm{EU}$ countries (out of the 35 countries analysed in the survey) — that is to say, the result of 29,719 face-to-face interviews with employees and 5,491 with the self-employed (out of the 43,850 conducted for the entire survey). Unless otherwise indicated, all the data mentioned below relate exclusively to employees and come from the European Working Conditions Survey (EWCS) (Eurofound, 2016).

To account for the significant trends in Europe, we have deliberately favoured European averages, even though these may conceal significant disparities between countries, regions or groups of workers. This chapter is not intended to report systematically on these intra-European disparities.

\subsection{Diffuse Growth of Socio-Economic Insecurity}

Various indicators can testify to the socio-economic insecurity affecting the working population, including the four mentioned below.

The first is the form of the employment contract that binds employees to their employers. The fixed-term contract, the temping agency contract and those contracts that embody all the other statuses involve a finite period of work and, often, less access to the protection and social benefits to which the 
standard full-time contract of indefinite length gives entitlement (coverage in case of sickness or invalidity, unemployment benefit, maternity leave, etc.).

According to the Eurostat Labour Force Survey (Eurostat 2016), temporary contracts accounted for 14 per cent of total employment in the EU-28 in 2016, but 32 per cent for the under-3os. A total of 62 per cent of the people concerned accepted these contracts because they could not find a permanent job. Part-time employment, which grew steadily, affected one in five European employees in the same year, but this figure concealed large disparities between countries and by sex. In addition, a large majority of young people entered the labour market through atypical employment. According to the 2015 EWCS survey, only 60 per cent of employees under 30 years of age were in permanent employment.

In 2015, 16 per cent of European employees lived in fear of losing their job during the next six months (11 per cent of employees on permanent contracts, but this figure was 43 per cent for employees on fixed-term contracts and 32 per cent for employees with other contractual arrangements). This indicator of socio-economic insecurity increased by three percentage points between 2005 and 2015. A number of prospective studies (Dickerson and Green, 2009; Green, 2015) have shown that, in most cases, it heralded significant job losses.

The second indicator is the number of employees who feel it would be difficult for them to find a job as well-paid as their current job, should they lose it. In 2015, almost half of employees expressed this feeling.

The third determinant of socio-economic insecurity, and arguably the most telling one, is the level of remuneration. The proportion of employees classified as in the lowest income quintile ${ }^{3}$ in 2015 was 13 per cent for permanent employees, but $3^{1}$ per cent for fixed-term employees and 57 per cent for employees holding other types of contracts.

Finally, the fourth indicator is the proportion of workers' households that report having difficulties in 'making ends meet'-more than a third of the people at work in $2015^{4}$ (35 per cent, as against 38 per cent in 2010). These perceived economic difficulties were more common among employees with fixedterm contracts ( 48 per cent) or other contractual arrangements ( $5^{2}$ per cent) than among permanent contract holders (31 per cent). According to the latest Benchmarking Europe report (ETUI, 2017), the number of poor workers ${ }^{5}$ in

3 In all, 20 per cent of those surveyed refused to answer this question: if we are to believe some of the multifarious analyses of these non-respondents, the incomes noted by the EWCS are too low.

4 The expression 'people at work' designates employees and the self-employed.

5 'Poor workers' are persons who have worked throughout most of the reference year but who live in a household whose income per unit of consumption falls under the threshold of the 
Europe is growing (nearly one in ten workers in 2017), particularly among the self-employed, those with low qualifications (International Standard Classification of Education [ISCED] 0-2) and employees on temporary or part-time contracts. In addition, new forms of insecure employment will arise from the advent of the digital economy and the rapid proliferation of 'small jobs' available online (Valenduc and Vendramin, 2016), a phenomenon that Ursula Huws (2003) has described as the 'cybertariat'.

Flexicurity thus seems not to have kept all its promises in the European Union. The employees most exposed to socio-economic insecurity are the holders of fixed-term contracts and, even more, the holders of so-called 'atypical' contracts, employees with low seniority, agricultural workers and those in 'basic' occupations, part-time employees, women — more than men-and older workers.

\subsection{Working Conditions}

The notion of working conditions has widened as certain aspects of working life have become more visible, were removed from the 'naturalness of work' and taken into consideration. Exposure to risk, non-standard working hours and work intensity will be covered here.

The health and safety policies of the member states of the European Union have long sought to eliminate-either totally or by substitution - the risks, in particular the physical risks, likely to harm workers' health. But, as can be seen in Figure 13.2, technical progress and the spread of new technologies have not removed these physical risks from various work environments.

In 10 years, only exposure to tobacco smoke has changed significantly (11 per cent lower). Musculoskeletal disorders have spread. They now affect millions of workers and cost employers billions of euros (Eurofound, 2016). These disorders result from physical factors - such as repetitive movements, heavy loads, frequent bending and twisting, exposure to cold, and insufficient time for recovery — but also from certain psychosocial factors (da Costa and Viera, 2010).

The occupational groups most exposed to physical hazards are machine operators, manual workers and those in basic occupations. All other occupations are exposed to some of the most common physical hazards that, along with stress, can cause musculoskeletal disorders. For example, about half of managers, professionals and technicians (International Standard Classification of Occupations [ISCO] 1) say that they perform repetitive movements with their

risk of poverty, fixed at 60 per cent of the median income. See the website http://ec.europa.eu/ eurostat/statistics-explained/index.php/EU_statistics_on_income_and_living_conditions _(EU-SILC)_methodology_-_in-work_poverty (accessed on 31 July 2018). 


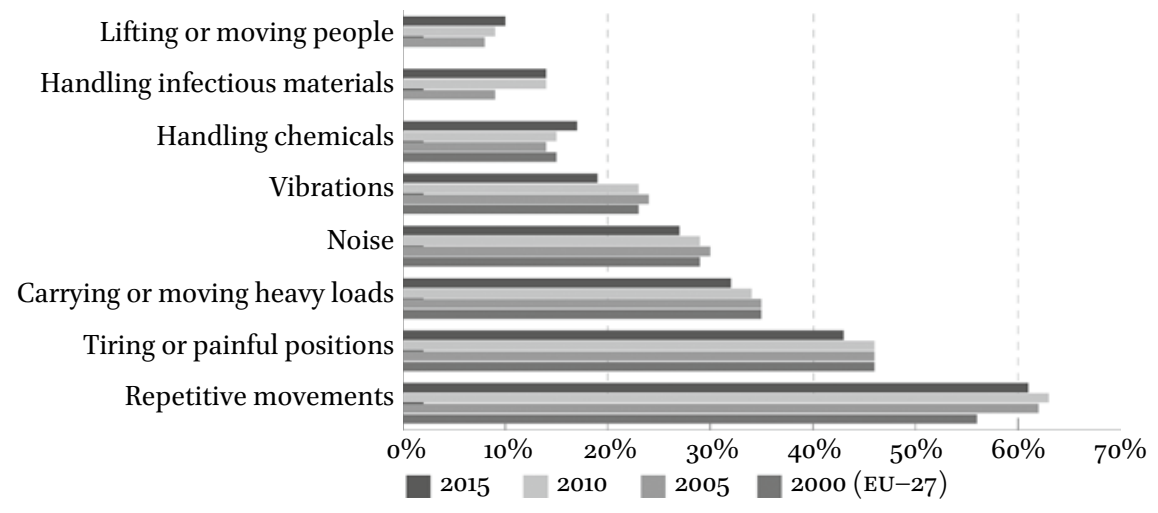

FIgURE 13.2 Exposure to Physical Risks

SOURCE: EUROFOUND (2016).

hands or arms for at least a quarter of their working time. In addition, more than 25 per cent of them say they have to adopt painful or tiring positions for more than a quarter of their working time. Workers in the services sector, meanwhile, have an exposure equal to or above the European average.

The fact that service and office activities also involve exposure to physical risks shows the need to continue to develop physical facilities in all work environments and to implement preventive programmes based on the actual activity of workers as a whole. In some work settings where activity is particularly intense, workers are not always able to adopt the safest behaviours. They may choose the quickest option, even if it is more 'dangerous'.

In addition, some practices related to working time-long and irregular schedules and overtime, and schedules that are difficult to control or are unpredictable - may pose a health risk while others, such as flexibility when tailored to staff needs, provide real room for manoeuvre. These time factors can predict a poor balance between private and professional life. Atypical schedules may, however, be suitable for some people for personal reasons, and to others at certain stages of their lives.

Due to the increase in part-time work and the decrease in long hours, the average number of working hours has decreased. The number of people working long hours (more than 48 hours per week) decreased between 2005 and 2015, from 19 per cent to 16 per cent. Likewise, only 32 per cent of people at work said they had working days of at least 10 hours in 2015 , compared to 36 per cent in 2005. But 23 per cent said they had, at least once during the previous month, worked two days in succession separated by a break of less than 11 hours.

Shift work is on the rise (four percentage points more in 10 years), as are working Sundays (two percentage points more, notably due to legislative 
changes related to stores' opening hours). In addition, employees are working frequently on Saturdays - $5^{2}$ per cent had worked on a Saturday at least once in the month prior to the survey. Night work is practised at least once a month by 19 per cent of people at work.

In the majority of cases $\left(5^{6}\right.$ per cent of people at work and 64 per cent of employees), the hours worked are determined by the employers - a figure unchanged for ten years. In all, 9 per cent of people at work (1o per cent of employees) can choose from several schedules and nearly 20 per cent of them can adapt their schedules. Only 7 per cent of employees (and 16 per cent of people at work) can choose their working hours freely. In seven out of ten cases, working hours do not change; 13 per cent of people at work have work schedules that change the same day or the day before; and 12 per cent of them can be called to work with very little prior notice.

Very regular schedules (i.e. working the same number of hours per day, the same number of hours per week and the same number of days per week with fixed times for the beginning and end of the day) involve just under half of employees (a little over a third of employees with atypical contracts). Work during one's free time is frequent: 19 per cent of European employees now work in their free time several times a month (and several times a week in 8 per cent of cases) to meet the requirements of their jobs. This figure conceals large disparities according to professional profiles: more than a third of the most highly-qualified white-collar workers see their free time encroached upon.

Finally, there is an increase in workload, and especially in the intensity of work. Employees have to work faster, carry out more demanding tasks, and have jobs that are richer in emotions: so they must reconcile a diverse set of factors regulating the pace of work, thus adding operational constraints and complicating their task. Especially over long periods, these new constraints have adverse consequences for the health and well-being of workers. According to the EWCS survey, 37 per cent of employees work 'to tight deadlines' and 34 per cent 'at high speed' for more than three quarters of their working time (figures that have not decreased since 2005). In addition, numerous epidemiological studies have shown that workers subjected to very intense activities have an increased risk of health problems (cardiovascular diseases, musculoskeletal disorders, depression, etc.), especially when they have to meet multiple demands while having limited autonomy and little support (Karasek, 1979; Karasek and Theorell, 1992; Siegriest, 1996).

\subsection{More Expressive Expectations, Not Necessarily Satisfied}

The instrumental component of work - security and income-remains essential, but professional activity has become a vector of social connection and the site of strong expressive expectations: to blossom in one's work, to develop 
one's skills, to be recognised, to find meaning in one's work, to do useful work, etc. (Inglehart and Baker, 2000; Mercure and Vultur, 2010; Bigi et al., 2015; Méda and Vendramin, 2016). These expectations of development and personal fulfilment in work have become increasingly important since the 1950s. This relative effacement of the instrumental and painful dimension of work in favour of another dimension, more related to the activity itself and its consequences for the individual, took place in two stages. It was theorised in the nineteenth century (notably by Hegel and Marx) and came to fruition in the second half of the twentieth century, when the conditions for its implementation were met (Lalive d'Epinay, 1994). According to Christian Lalive d'Epinay, two essential events marked the history of the disappearance of the ethos of duty: on the one hand, the development of the welfare state and the idea that it is incumbent upon it to guarantee the well-being of its citizens, and, on the other hand - and above all - the explosion of economic growth that suddenly made accessible the utopia of work-pleasure; that is to say, the transformation of tripalium or work-duty into an instrument of self-realisation and self-expression. In this shift from an ethic of duty to an ethic of fulfilment, Lalive d'Epinay sees a fundamental reversal: society is now at the service of the fulfilment of individuals who, before, found self-realisation in carrying out the mission with which society had entrusted them.

Some of the indicators in the EWCS survey relate to this expressive component of work: the use and development of employees' skills, autonomy and the social environment. The majority of European employees report that their job gives them job satisfaction (8o per cent) and have the feeling of doing useful work (84 per cent). But 16 per cent of them do not feel that they receive the recognition they deserve for their work and only 38 per cent think they have career prospects.

In these times of flexicurity and uncertainty, employees doubt their professional future and attach great importance to being able to use and develop their skills. Thus, 71 per cent of them say that their job involves learning new things, but this is not the case for the remaining 29 per cent. Nearly half of employees ( 46 per cent) say they perform monotonous tasks, but just as many feel they can apply their own ideas into their work (27 per cent sometimes and 25 per cent never).

Life-long training is a European issue in the 'Education and Training 2020' strategic framework. The survey shows that 41 per cent of employees received training paid for by their employers during the previous 12 months. The most qualified of them have access to more and longer-term training.

In terms of autonomy, the situations are contrasted. About 65 per cent of employees can choose or change the order of the tasks they have to perform, their working speed and the methods applied. Only a quarter of them have a 
say in choosing their colleagues. The participation of employees in decisions concerning the organisational aspects that concern them remains limited: 44 per cent of them are consulted prior to their objectives being set; 44 per cent are involved in improving the organisation and work processes of their department; and 41 per cent have an influence on the important decisions that concern them.

Only a third of employees are autonomous in the performance of their tasks and also have the opportunity to be heard and to contribute to the development of the organisation. Conversely, 34 per cent have no opportunity to exercise their autonomy and contribute to the development of the organisation. The situation in this area is therefore still far from optimal.

Work can also be an opportunity to meet new people and belong to a professional community. In most cases, this experience is positive. But sometimes it is less so, especially when people at work are victims of certain forms of violence, when they are not supported by their colleagues or their superiors, or when they are placed under the authority of a manager unable or unwilling to help and encourage them.

For more than two-thirds of employees, the social climate in which they operate is positive: 69 per cent say that employees generally trust their management, 71 per cent say that conflicts are resolved in a fair way, 73 per cent feel that the work is distributed equitably and 82 per cent feel that management trusts the employees to do their job well. Finally, 89 per cent of employees say they work well with their colleagues.

Many employees benefit from social support within the company if a problem arises: 72 per cent of them say they have-always or nearly always-the support of their colleagues, while $5^{8}$ per cent say they are supported by their superior in the hierarchy. They feel respected by the latter in nine out of ten cases; but 5 per cent of employees say they are never or almost never respected by this same superior. About seven out of ten employees appreciate the technical skills of their manager: 66 per cent feel that their superior is helpful in getting the job done better; 70 per cent say that their supervisor provides useful feedback on their work; 71 per cent say they are congratulated and recognised by their supervisor when they do a good job; and 73 per cent report that their superior is successful in getting people to work together. Just under seven in ten (68 per cent) feel encouraged and supported by their manager in their professional development. But this figure should not overshadow the fact that more than three in ten employees say they are poorly managed.

\subsection{Health Indicators Revealing the Ageing Labour Force}

The sixth EWCS survey provides a number of indicators on the perceived health and subjective well-being of workers based on the wHO-5 World Health 
Organization index. ${ }^{6}$ This index assesses different aspects (positive mood, vitality and general interest) to calculate a score between $o$ and 100. On average, the subjective well-being of workers is quite high in Europe (68 points out of 100). But a quarter of European employees (25 per cent) say that their health is threatened by their work; 41 per cent suffer from muscle pain in the shoulders, neck and/or upper limbs and 29 per cent from muscle pain in their lower limbs. The impact of working conditions on the health of workers is a significant cost to the company and the community.

Numerous other indicators measure the prevalence of certain symptoms (including sleep disorders, general fatigue, anxiety and stress) and provide a better understanding of how these disorders relate to certain organisational or occupational characteristics. Thus, 35 per cent of European employees suffered from general fatigue during the twelve months preceding the survey, 18 per cent from insomnia or sleep disorders (several times a week) and 15 per cent from anxiety. More women than men suffer from general fatigue, insomnia and sleep disorders. A significant proportion of European employees also report having been confronted with stress in the course of their work: almost 10 per cent 'always', 17 per cent 'most of the time', 40 per cent 'sometimes', 20 per cent 'rarely' and 13 per cent 'never'. More than one in four employees state that they are regularly exposed to stress in the course of their work. Exposure to stress differs with occupation. It is frequent in management functions (34 per cent) as well as in the category of professionals ${ }^{7}$ ( 29 per cent), among plant and machine operators (29 per cent) and among service workers and technicians, as well as clerks ${ }^{8}$ ( 26 per cent). Disparities between countries are also significant.

This survey highlights the fact that lack of time to do one's job is one of the main factors of stress. European employees who say they 'never' or 'rarely' have the time necessary to perform their work ( 55 per cent) also report being regularly confronted with stress in their jobs. Only 27 per cent of European employees say they have always enough time to do their jobs. It should be noted

6 For more information on the index, see the website https://www.psykiatri-regionh.dk/who-5/ who-5-questionnaires/Pages/default.aspx (accessed on 31 July 2018).

7 This category includes the professions of engineering, architecture, research, management, marketing, IT, law, social sciences, culture, media; artists, doctors, nursing managers, chemists, dentists, paramedics, and those involved in any of the levels of education including training outside of the school environment.

8 This category includes those working in accounting, finance, property, commercial services, specialised secretaries, social workers, customs inspectors, those working in tax, the police, sports, arts and leisure activities; technicians in industry, in laboratory work, in transport, supervisors, inspectors, ICT and media technicians; technicians and assistants in medicine and the paramedical domain, nurses and midwives, and health officials. 
that employees in structures that experienced significant restructuring or reorganisation during the three years preceding the survey were more likely to report being exposed to stress on a regular basis. The same phenomenon is observed in those who have recently experienced the implementation of new processes or new technologies or who report a feeling of insecurity in their jobs. Employees who fear losing their jobs in the next six months are thus more likely to declare themselves exposed to stress in their work.

Finally, the retention of older workers-which is essential for European economies-is highly dependent on working conditions. Based on 2010 data from the EwCs survey, the Eurofound report shows that the retention of the oldest employees in working life is strongly correlated with working conditions (Vendramin et al., 2012). The most unfavourable factors for such retention are a rapid pace of work, exposure to physical risks, painful postures, night work or shift work, a lack of balance between work and personal life, and, finally, being confronted with aggressive behaviour or harassment.

\subsection{The Return of a Balance between Work and Private Life}

For several decades, the work-life balance, formerly known as the work-family balance, has been a recurring theme on the job scene. This new term has not been chosen at random: the notion of balance questions work itself. The idea of work-family balance was essentially aimed at adapting private life to work - that is to say, supporting workers in their private lives so as to enable them to carry out their professional activities. This issue is again on the agenda in a context in which workers-especially the youngest of them-have a new relationship with their work.

Dominique Méda and Patricia Vendramin (2016) conducted a large-scale research project in six European countries, ${ }^{9}$ in which they highlighted convergences in the development of the work relationship. Two of these convergences relate directly to this quest for balance between work and private life. First, there is a rejection of the hegemonic place given to work and a desire to tackle projects in various fields. If work remains an important value for Europeans,

9 SPReW (Social patterns of relationship to work/Intergenerational dimensions in changing relations to work). European research carried out under the 6th Framework Programme for Research of the European Union. The research brought together eight partners and six countries (Germany, Belgium, France, Hungary, Italy and Portugal) from June 2006 to September 2008. It drew inter alia on a qualitative approach (150 narrative interviews and 18 group interviews in total) conducted in the six countries as well as on quantitative data from international (European Value Survey [Evs], European Social Survey [ESs], International Social Survey Programme [ISSP]) and national surveys. For more information, see the website http://www.ftu-namur.org/sprew (accessed on 19 June 2018). 
they also express the wish to be able to flourish in other spheres of life that all contribute to the building of their identity-family in particular, but also friends, hobbies, social life and civic life. For both women and men, the hegemony of labour-value has given way to a multi-centred conception of life: this development makes it all the more necessary to redefine the modalities of the balance between professional life and private life-especially for expenses relating to care. Méda and Vendramin highlighted an increasing closeness between male and female models of commitment to work, particularly obvious in the case of younger generations of workers. This phenomenon could be defined as a feminisation of the masculine model coupled with a masculinisation of the feminine model. In their relation to work, young men seem more guided by expressive aims and by changes in the perception of their role as fathers. Despite a still very unequal division of roles, this new engagement of men in the family increases with the level of education of the male partner as well as in families where both partners are active. In addition, young women - who, on average, have a higher level of education than their male counterparts-are seeking to become fully engaged in working life and no longer perceive themselves as providing supplementary wages. Young women are increasingly building their social identity from their work. This convergence of gender models in the work relationship-especially for young graduates-is an incentive for human resources managers to question the retention of young graduates and to take into account the new types of compromises that young male executives are willing to make in order to balance working and family life.

According to the EWCS survey, 82 per cent of employees feel their work hours fit in with family or social commitments outside of work. This proportion has changed little since 2005. The remaining 18 per cent believe, on the contrary, that their working hours do not suit their private lives, but this figure conceals large disparities between countries. A total of 63 per cent of employees can easily come to an arrangement with their employer involving an hour or two's work when family reasons are concerned. In the remaining 37 per cent, we more commonly find employees with long working days (48 hours a week or more), those who take work home and those working nights, shifts or weekends.

Conflicts between private and professional life have negative consequences for both workers and companies: the employees concerned can suffer a deterioration in their psychological balance and health, and they may also be less involved in their work. According to the survey, around 20 per cent of employees say they are too tired to carry out the necessary household chores. In addition, 12 per cent of them think about their work during their free time and 11 per cent say they cannot spend as much time as they would like with their 
families because of their work. Importantly, family problems seem to weigh less heavily on work than work-related problems do on the family. Only 3 per cent of employees say they have difficulty concentrating on their work because of family responsibilities or have not spent as much time as they wanted to at work because of family responsibilities. Finally, a good balance between work and private life is also a factor in keeping older workers in employment (Vendramin et al., 2012).

\section{$4 \quad$ Sustainable Work: A Desirable Horizon?}

These data on current working conditions in Europe need to be put into perspective, especially by taking into account the significance of work in our Western societies. Dominique Méda and Patricia Vendramin (2016) have attempted to interpret, in a historical and comparative perspective, the contemporary meaning of work. They have identified three types of worker-specific expectations, which are the result of historical developments that cannot be discussed here, ${ }^{10}$ but which shape the current relationship to work. First, work must ensure the security of existence. These so-called instrumental expectations make it a means to an end - to provide income and security. Second, work is a provider of social links. It is important to develop quality social relationships with colleagues, the hierarchy and other partners in the activity-subcontractors, customers or users. Finally, work must satisfy the expressive expectations of workers, their need to develop and flourish in their professional activity. Recognition, meaningful work, learning and sense of purpose: the labour force aspires to all these factors of well-being, now that it is overall better trained and partly relieved of the weight of the instrumental component of labour thanks to the development of the welfare state since the post-war years. These expressive expectations come up against often unsuitable modes of organisation. Therefore, the process of redefining working conditions must imperatively take into account this dissatisfaction and reconnect the world of work and its changing nature to the expectations of Europeans. Indeed, the desire to create jobs without regard to their quality and to promote all-round flexibility is currently threatening social cohesion in Europe, increasing inequalities and undermining the well-being of the population in most European states. Therefore, social justice and inclusive development must follow other routes.

10 For the historical developments, see Méda and Vendramin, 2016, pp. 7-47. 
Thanks to the twenty key principles of the European Pillar of Social Rights, ${ }^{11}$ job quality has returned to the public arena. The European Commission encourages permanent employment, social dialogue and worker participation, healthy and adapted workplaces, secure employment for a fair wage, and finally a balance between professional life and private life.

Sustainable work is a desirable horizon for Europe, insofar as it is likely to underlie a multidimensional approach to quality of work that will take into account working individuals as a whole, with their characteristics, their constraints and their trajectories. The ILO could also choose this direction, which is already reflected in the many points raised during the national dialogues on the future of work (ILO, 2017). Moreover, since the concept of sustainable work initially brought together two issues - that is to say, sustainable development and working systems - it could probably be used to combine the priorities of sustainable development and decent work. It could also contribute to a reaffirmation of the humanistic and social principles of the Declaration of Philadelphia (ILO, 1944) and lead us to a society in which 'labour is not a commodity' and in which 'all human beings [...] have the right to pursue both their material well-being and their spiritual development in conditions of freedom and dignity, of economic security and equal opportunity' (ILO, 1944, Article II(a)).

\section{References}

Barbier, J-C. (2007) 'Au-delà de la "flex-sécurité", une cohérence sociétale solidaire au Danemark', in S. Paugam (ed.), Repenser la solidarité, l'apport des sciences sociales (Paris: PUF), pp. 473-490.

Barisi, G. (2011) 'Les systèmes de travail soutenable, une composante souvent négligée mais fondamentale du développement durable', Innovations, 2/2011, 35, pp. 67-87, DOI: 10.3917/inno.035.0067.

Bevort, A., M. Lallement and C. Nicole-Drancourt (2006) 'Flexicurité. La protection de l'emploi en débat', Problèmes politiques et sociaux, 931, pp. 5-10.

Bigi, M., O. Cousin, D. Méda, L. Sibaud and M. Wieviorka (2015) Travailler au XXIe siècle :Des salariés en quête de reconnaissance (Paris: Robert Laffont).

Bothfeld, S. and J. Leschke (2012) “More and better jobs": Is quality of work still an issue - and was it ever?', Transfer, 18(3), pp. 337-353, DOI: 10.1177/1024258912448602.

11 See the principles on the website https://ec.europa.eu/commission/priorities/deeper -and-fairer-economic-and-monetary-union/european-pillar-social-rights/european -pillar-social-rights-20-principles_en (accessed on 31 July 2018). 
Brown, A., A. Charlwood, C. Forde and D. Spencer (2007) 'Job quality and the economics of New Labour: A critical appraisal using subjective survey data', Cambridge Journal of Economics, (31), pp. 941-971, DOI: 10.1093/cje/bemo28.

da Costa, B.R. and E.R. Vieira (2010) 'Risk factors for work-related musculoskeletal disorders: A systematic review of recent longitudinal studies', American Journal of Industrial Medicine, Vol. 53, No. 3, pp. 285-323, DOI: 10.1002/ajim.20750.

Davoine, L., C. Erhel and M. Guergoat-Larivière (2008) A Taxonomy of European Labour Markets Using Quality Indicators, Final report for the European Commission, Centre d'études de l'emploi, May, 45, https://halshs.archives-ouvertes.fr/halshs-00317280/ document (accessed on 23 August 2018).

Dickerson, A. and F. Green (2009) 'Fears and realisations of employment insecurity', Labour Economics, Vol. 19, No. 2, pp. 198-210, DOI: 10.1016/j.labeco.2011.10.001.

Docherty, P., J. Forslin and A.B. Shani (2002) Creating Sustainable Work Systems (London and New York: Routledge).

ETUI (European Trade Union Institute) (2017) Benchmarking Working Europe (Brussels: ETUC and ETUI), https://www.etui.org/Publications2/Books/Benchmarking -Working-Europe-2017 (accessed on 19 June 2018).

Eurofound (2016) Sixth European Working Conditions Survey (Luxembourg:Publications Office of the European Union), https://www.eurofound.europa.eu/fr/publications/ report/2016/working-conditions/sixth-european-working-conditions-survey -overview-report (accessed on 31 July 2018).

Eurofound (2012) Fifth European Working Conditions Survey (Luxembourg: Publications Office of the European Union), https://www.eurofound.europa.eu/sites/default/ files/ef_publication/field_ef_document/efi182en.pdf (accessed on 31 July 2018).

Eurofound(2002) QualityofworkandemploymentinEurope-Issuesandchallenges, Foundation paperNo.1(Luxembourg: Office for Official Publications of the European Communities), https:/www.eurofound.europa.eu/fr/publications/foundation-paper/ 2002/working-conditions/quality-of-work-and-employment-in-europe-issues -and-challenges-foundation-paper-no-1-february-2002 (accessed on 31 July 2018).

European Commission (2007) Towards Common Principles of Flexicurity: More and better jobs through flexibility and security (Luxembourg: Office for Official Publications of the European Communities), http://ec.europa.eu/social/BlobServlet?docId $=2756$ \&langId=en (accessed on 31 July 2018).

EUROSTAT (European Statistical Office) (2016) European Union Labour Force Survey 2016 (Luxembourg: EUROSTAT), http://ec.europa.eu/eurostat/web/lfs/data/main -tables (accessed on 31 July 2018).

Ghai, D. (2003) 'Decent work: concept and indicators', International Labour Review, 142(2), pp. 121-158, http://ilo.ch/public/english/revue/download/pdf/ghai.pdf (accessed on 20 June 2018). 
Gollac, M., S. Guyot and S. Volkoff (2008) A propos du «travail soutenable », Rapport de recherche 48 (Noisy-Le-Grand Cedex: Centre d'études de l'emploi), http://www .ladocumentationfrancaise.fr/rapports-publics/084000571/index.shtml (accessed on 31 July 2018).

Green, F. (2015) 'Health effects of job insecurity', IZA World of Labour, https://wol.iza .org/uploads/articles/212/pdfs/health-effects-of-job-insecurity.pdf?v=1 (accessed on 20 June 2018).

Green, F. (2006) Demanding Work. The Paradox of Job Quality in the Affluent Economy (Princeton and Oxford: Princeton University Press).

Green, F. and T. Mostafa (2012) Trends injob quality in Europe (Luxembourg:Publications Office of the European Union), https://www.eurofound.europa.eu/fr/publications/ report/2012/working-conditions/trends-in-job-quality-in-europe (accessed on 23 August 2018).

Holman, D. and C. McClelland (2011) Job Quality in Growing and Declining Economic Sectors of the EU, Walqing Working Paper 2011. 3, http://www.research.mbs.ac.uk/ ewerc/Portals/o/docs/Latest\%2oPublications/WALQING\%2oFINAL\%2oREPORT \%20Job\%2oquality\%2oin\%2othe\%2oEU.pdf (accessed on 20 June 2018).

Huws, U. (2003) The Making of a Cybertariat: Virtual Work in a Real World (New York: Monthly Review Press).

ILO (International Labour Organization) (2017) Synthesis Report of the National Dialogues on the Future of Work (Geneva: ILO), http://www.ilo.org/wcmsp5/groups/ public/---dgreports/---cabinet/documents/publication/wcms_591505.pdf(accessed on 31 July 2018).

ILO (1944) Declaration concerning the aims and purposes of the International Labour Organisation, (Philadelphia Declaration), International Labour Conference, Record of Proceedings, 26th Session, Philadelphia, 10 May, (Geneva: ILO), http://www.ilo .org/public/libdoc/ilo/1944/44Bo9_10_e_f.pdfpp. 621-623 (accessed on 1 December 2018).

Inglehart, R. and W.E. Baker (200o) 'Modernization, Cultural Change, and the Persistence of Traditional Value?', American Sociological Review, 65(1), pp. 19-51, http:// www.jstor.org/stable/2657288 (accessed on 20 June 2018).

Karasek, R.A. (1979) 'Job demands, job decision latitude, and mental strain: Implications for job redesign', Administrative Science Quarterly, Vol. 24, No. 2, pp. 285-308, http://www.jstor.org/stable/2392498 (accessed on 20 June 2018).

Karasek, R.A. and T. Theorell (1992) Healthy Work: Stress, Productivity, and the Reconstruction of Working Life (New York: Basic Books).

Lalive d'Epinay, C. (1994) 'Significations et valeurs du travail, de la société industrielle à nos jours', in M. De Coster and F. Pichault (eds.) Traité de sociologie du travail (Brussels: De Boeck), pp. $55^{-82 .}$ 
Leschke, J. and A. Watt (2008) Putting a Number on Job Quality? Constructing a European Job Quality Index (Brussels: ETUI), https://www.etui.org/Publications2/ Working-Papers/Putting-a-number-on-job-quality (accessed on 19 June 2018).

Méda, D. and P. Vendramin (2016) Reinventing Work in Europe (Basingstoke: Palgrave Macmillan).

Mercure, D. and M. Vultur (2010) La signification du travail. Nouveau modèle productif et ethos du travail au Québec (Québec: Presses de l'Université Laval).

Muñoz de Bustillo, R., E. Fernandez-Macias, J.I. Anton and F. Esteve (2009) Indicators of Job Quality in the European Union (Brussels: European Parliament), http:// www.europarl.europa.eu/document/activities/cont/201107/20110718ATT24284/ 20110718ATT24284EN.pdf (accessed on 20 June 2018).

Prieto, C.R. and A. Serrano Pascual (2014) 'Du travail décent à la qualité de l'emploi: enjeux épistémologiques et politiques d'un changement de paradigme', La nouvelle revue du travail, 4/2014, DOI: 10.4000/nrt.1639.

Serrano Pascual, A. (ed.) (2012) 'La flexicurité - Mutation symbolique de la notion de sécurité', Les politiques sociales, 3 \& 4 .

Serrano Pascual, A. (2008) 'Batailles d'idées dans l'espace européen: la lutte contre le chômage et le combat pour le nommer', Revue de l'IRES, 6o, pp. 47-64, DOI:10.3917/ rdli.o6o.0047.

Siegrist, J. (1996) 'Adverse health effects of high-effort/low-reward conditions', Journal of Occupational Health Psychology, Vol. 1, No. 1, pp. 27-41, https://pdfs .semanticscholar.org/79da/feogb439dff93docf4f4aod231fff321eoa4.pdf (accessed on 20 June 2018).

Valenduc, G. and P. Vendramin (2016) Work in the digital economy: sorting the old from the new (Brussels: ETUI).

Vendramin, P., G. Valenduc, A.-F. Molinié, S. Volkoff, M. Ajzen and E. Léonard (2012) Sustainable work and the ageing workforce (Dublin: Eurofound), https://www .eurofound.europa.eu/publications/report/2012/working-conditions-social -policies/sustainable-work-and-the-ageing-workforce (accessed on 20 June 2018).

WCED (World Commission on Environment and Development) (1987) Our Common Future (Oxford: Oxford University Press), http://www.un-documents.net/our-common -future.pdf (accessed on 31 July 2018). 